\title{
Carbon Sequestration in Tropical and Subtropical Plant Species in Collaborative and Community Forests of Nepal
}

\author{
Ram Asheshwar Mandal, ${ }^{1}$ Pramod Kumar Jha, ${ }^{2}$ Ishwar Chandra Dutta, ${ }^{3}$ \\ Utsab Thapa, ${ }^{4}$ and Siddhi Bir Karmacharya ${ }^{5}$ \\ ${ }^{1}$ Department of Forests, Babarmahal, Kathmandu, Nepal \\ ${ }^{2}$ Central Department of Botany, Kirtipur, Kathmandu, Nepal \\ ${ }^{3}$ Tribhuvan University Commission, Kirtipur, Kathmandu, Nepal \\ ${ }^{4}$ District Forest Office, Hattisar, Kathmandu, Nepal \\ ${ }^{5}$ Tri-Chandra College, Ghantaghar, Kathmandu, Nepal
}

Correspondence should be addressed to Ram Asheshwar Mandal; ram.mandal@gmail.com

Received 9 December 2015; Revised 7 April 2016; Accepted 12 April 2016

Academic Editor: Junbao Yu

Copyright (C) 2016 Ram Asheshwar Mandal et al. This is an open access article distributed under the Creative Commons Attribution License, which permits unrestricted use, distribution, and reproduction in any medium, provided the original work is properly cited.

\begin{abstract}
Different plant species have different capacity of carbon sequestration but it is not assessed yet in Nepal. Therefore, this study was done to assess the species-wise carbon sequestration in two periods in forests. Three collaborative and three community forests were selected for the study. The selected forests were surveyed using GPS and mapped and stratified into tree, pole, and regeneration. Specifically 32, 33, and 31 samples were collected from Banke-Maraha, Tuteshwarnath, and Gadhanta-Bardibash collaborative forests, respectively, while 30, 25, and 22 samples were collected from Chureparwati, Buddha, and Chyandanda community forests correspondingly. The sample plots were of $25 \mathrm{~m} \times 20 \mathrm{~m}$ for tree strata. The diameter and height of plants were measured and samples were collected for three consecutive years. The estimated carbon stock of Shorea robusta was the highest $35.93 \mathrm{tha}^{-1}$ in 2011 which was slightly decreased to $34.43 \mathrm{tha}^{-1}$ in 2012 and reached $32.02 \mathrm{tha}^{-1}$ in 2013 in Banke-Maraha collaborative forest but it was the least 7.97, 8.92, and $10.29 \mathrm{tha}^{-1}$ in 2011, 2012, and 2013, respectively, in Chyandanda community forest. The highest carbon sequestration was recorded about $5.02 \mathrm{tha}^{-1}$ of Shorea robusta in Chyandanda community forest in between $\mathrm{t}_{2013}$ and $\mathrm{t}_{2012}$.
\end{abstract}

\section{Introduction}

There is no land on Earth where plants do not exist [1]. There are about 1 million plant species in the world out of which $20 \%$ are threatened with extinction [2]. People know the importance of plant because of the daily interrelationship with it [3]. It is a well-known fact that plants release oxygen that people breathe in. People use them kindly and unkindly though they know without plant life is impossible [4]. People plant the plants, grow them, and develop them into forests to meet their daily needs. Wise use of plants is good but when they are cut, damaged, and destroyed cruelly without thinking of the future [5], the consequences are extremely complex like global warming and climate change $[6,7]$. About $18 \%$ of greenhouse gases (GHGs) are released from such activities [8]. Inversely, halting these activities can cut the same proportion of GHGs emission which would be beneficial, thereby bringing the REDD+ (reducing emission from deforestation and forest degradation) mechanism into existence $[9,10]$.

Burden of deforestation and forest degradation is still very much challenging the living beings on Earth due to the increased production of greenhouse gases (GHGs) especially $\mathrm{CO}_{2}$ [11, 12]. In fact, the annual deforestation contributes about $5.9 \mathrm{Gt} \mathrm{CO}_{2}$ in the world [13]. Clearing of tropical forests

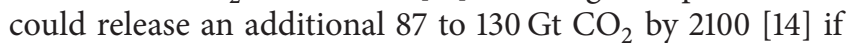
the rate of deforestation continuously increases at the same trend. Based on the base year 1994/95, Nepal's contribution of GHGs from all sources is about $9,747 \mathrm{Gg} \mathrm{CO}_{2}$ out of which $8,117 \mathrm{Gg} \mathrm{CO}_{2}$ is from the land-use change and forestry sectors [15]. Notably, the reverse actions like sustainable forest management, forest conservation, and forest enhancement as 


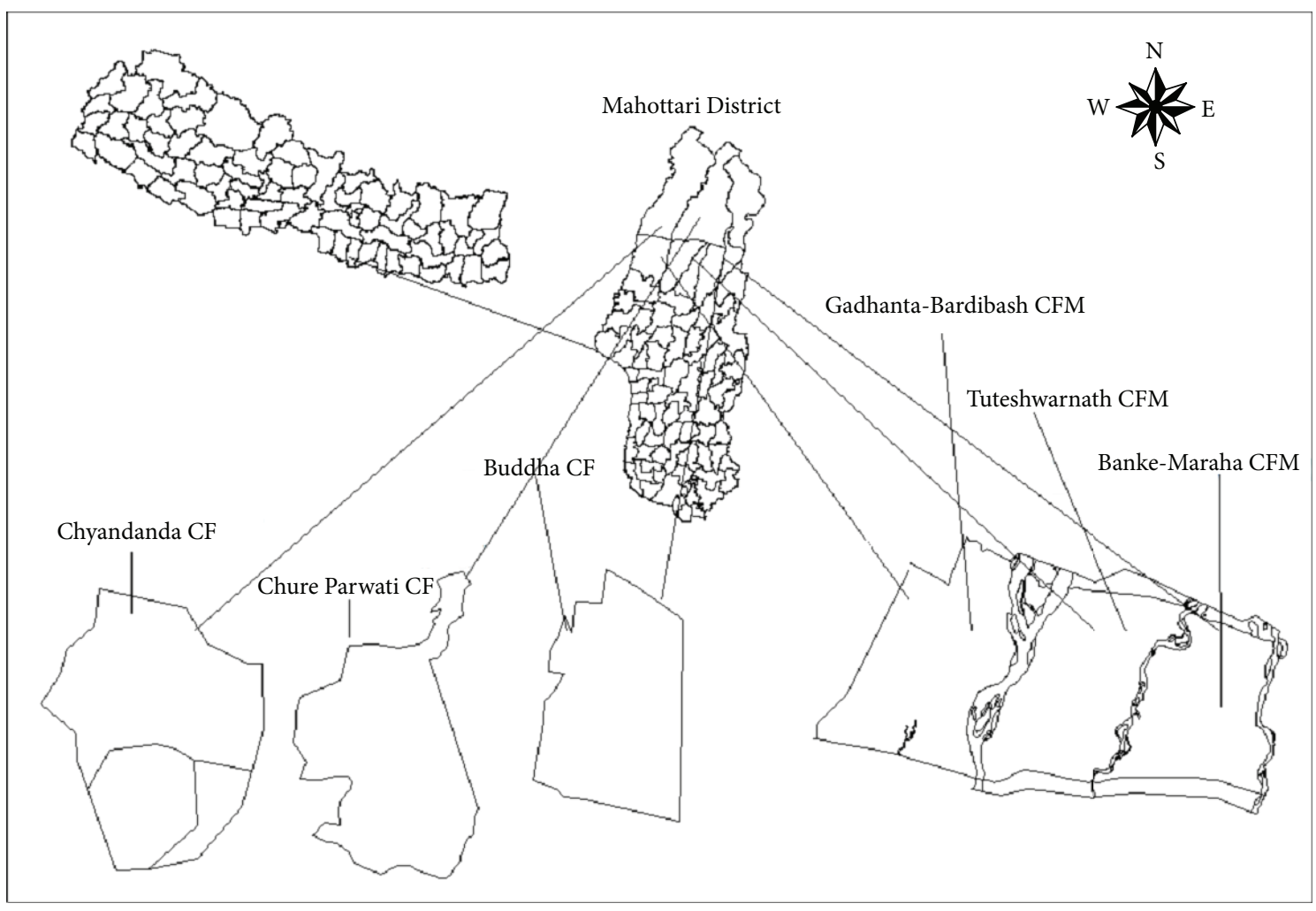

FIGURE 1: Map of study area.

carbon positive dynamics could reduce $\mathrm{CO}_{2}$ emission as a reward option under REDD+ mechanism $[11,16]$.

Different plant species have different capacity to sequestrate carbon during photosynthesis. Generally slow growing species have slow sequestration rate than others. Species like Shorea robusta, Terminalia tomentosa, and Adina cordifolia are some examples of slow growing plant species as they sequestrate carbon slowly. Then the research questions arise whether there are any differences in species-wise carbon stock in tropical and subtropical areas of Nepal and at the same time whether there is a difference in annual carbon sequestration rate within the same community managed forests. This study tries to answer these questions.

\section{Materials and Method}

2.1. Site Description. As this study deals with the tropical and subtropical plant species, Mahottari District of Terai region of Nepal that possesses tropical and subtropical plant species was selected as the study site. Three collaborative forests (CFMs), namely, Banke-Maraha (2,006 ha), Gadhanta-Bardibash (1,450 ha), and Tuteshwarnath (1,334 ha), and three community forests (CFs), namely, Chure Parwati (441.7 ha), Buddha (69.73 ha), and Chyandanda (41.35 ha) forests, were randomly selected (Figure 1). The geographical location of the district is $26^{\circ} 36^{\prime} \mathrm{N}$ to $28^{\circ} 10^{\prime} \mathrm{N}$ latitude and $85^{\circ} 41^{\prime} \mathrm{E}$ to $85^{\circ} 57^{\prime} \mathrm{E}$ longitude. The average temperature and rainfall recorded for the study were $20-250^{\circ} \mathrm{C}$ and $1,100-3,500 \mathrm{~mm}$, respectively. Generally July to October is the main rainy season which is the most favorable for plant growth. Sal (Shorea robusta) is the dominant species with other associates like Saj (Terminalia tomentosa), Botdhairo (Lagerstroemia parviflora), Harro (Terminalia chebula), and Barro (Terminalia belerica).

2.2. Experimental Design and Sampling. The research experiment and sampling methods are the most important part of a study. For this study, randomized block design (RBD) was set up and stratified random sampling was employed to collect data from forests [17]. Three main strata particularly tree (dbh $>30 \mathrm{~cm})$, pole $(\mathrm{dbh}=10-30 \mathrm{~cm})$, and regeneration $(\mathrm{dbh}<$ $10 \mathrm{~cm}$ ) were delineated. Survey was carried out with the help of GPS and map preparation and strata delineation were done using ArCGIS 10.2.

2.3. Data Collection. Biophysical data were collected from the field. So, the next step was to determine the adequate number of sample plots statistically. Pilot sampling was carried out in order to determine the number of sample plots based on statistical variability. For this purpose 10 samples were collected as presample of each stratum of collaborative and community forests at the beginning of the field work. After that, the records of diameter at breast height and height were taken and biomass was calculated which were used to find the adequate number of sample plots for each stratum. A total of 176 samples were collected out of which 32, 33, and 31 samples were collected from Banke-Maraha, Tuteshwarnath, and Gadhanta-Bardibash CFMs, respectively, while 30, 25, 
and 22 samples were collected from Chureparwati, Buddha, and Chyandanda community forests. Permanent sample plots were established using GPS receiver [18] and samples were collected for three consecutive years. Sample plots were randomly distributed on the strata. The centrepoint coordinates of sample plot were uploaded in GPS to navigate for establishing the plots in the field. The nested plots having $20 \mathrm{~m} \times 25 \mathrm{~m}$ for tree, $10 \mathrm{~m} \times 10 \mathrm{~m}$ for pole, $5 \mathrm{~m} \times 5 \mathrm{~m}$ for sapling, and $5 \mathrm{~m} \times 2 \mathrm{~m}$ for seedling were laid on the field. Then $\mathrm{dbh}$ and height of plants were recorded for $\mathrm{dbh}>5 \mathrm{~cm}$, while samples were collected from the plants having $\mathrm{dbh}<$ $5 \mathrm{~cm}[19]$.

2.4. Data Analysis. The data analysis included the determination of carbon stock, current annual carbon increment $(\mathrm{CACI})$, and $\mathrm{CO}_{2}$ sequestration.

2.4.1. Determination of Carbon Stock and CACI. Biomass calculation is the first estimation step to assess the carbon stock. Hence, the species-wise Above Ground Tree Dry Biomass (AGTB) was calculated using the biomass equation for samples with $\mathrm{DBH}>5 \mathrm{~cm}$ [20]. At the same time lab work was done to determine the dry biomass of plants having $\mathrm{DBH}<5 \mathrm{~cm}$. Besides, root-shoot ratio of 0.125 was used to determine the root biomass [21]. Subsequently, carbon stock was calculated by multiplying with default value 0.47 [22].

2.4.2. Formula Used for Carbon Analysis. Species-wise carbon stock change is as follows:

$$
\begin{aligned}
& \mathrm{C}=\text { carbon stock } n \text { year }- \text { carbon stock }(n-1) \text { year. } \\
& \text { Current annual carbon increment }(\mathrm{CACI})=\text { carbon } \\
& \text { stock } n \text { year }- \text { carbon stock }(n-1) \text { year. } \\
& \mathrm{CO}_{2} \text { sequestration }=\mathrm{CACI} * 44 / 12
\end{aligned}
$$

2.4.3. Statistical Analysis. The annual average carbon sequestration per ha for two years in each of the collaborative and community forests was compared using $Z$-test (for 30 and more samples) and $t$-test (for small samples) [23] using statistical software IBM SPSS, 20.

\section{Results}

3.1. Species-Wise Carbon Stock in Collaborative and Community Forests. The carbon change varied in different species in the collaborative and community forests. The carbon stock was found to be the highest in Shorea robusta as compared to other plant species as it is the dominant plant species in the forest [24]. The estimated carbon stock in Shorea robusta in Banke-Maraha collaborative forest was $35.93 \mathrm{t} \mathrm{ha}^{-1}$ in 2011 which slightly declined to $34.4393 \mathrm{tha}^{-1}$ in 2012 and further declined to $32.0293 \mathrm{tha}^{-1}$ in 2013. This shows carbon loss for this species, the reason of which could be the extraction of log from the forest. However, there were positive changes in carbon stock in other collaborative and community forests. The highest records of carbon changes were $1.37 \mathrm{tha}^{-1}$ and $0.95 \mathrm{tha}^{-1}$ in Chyandanda CF between first and second two consecutive periods, respectively, since the carbon stocks were 7.97, 8.92, and $10.29 \mathrm{tha}^{-1}$ in 2011, 2012, and 2013, respectively (Table 1). This is the indication of presence of young staged plants which have high carbon sequestration capacity.

3.2. Species-Wise Carbon Sequestration in Collaborative and Community Forests. Carbon sequestration in dominant species was higher than the other associate species. Carbon sequestration was the highest (5.02 $\mathrm{tha}^{-1}$ per annum) in Shorea robusta in Chyandanda CF between years 2012 and 2013. The reason behind this was the dominance of young pole stage plants in this forest whose photosynthetic rate is higher, thereby adding up more carbon during the pole stage. In addition, the current annual carbon increment is a reliable responsible factor to determine carbon sequestration which was found to be the highest in this CF. On the other hand, there was a leakage of about $8.87 \mathrm{tha}^{-1}$ annually between the years 2012 and 2013 in Banke-Maraha CFM (Table 2) due to the removal and damage to big sized trees.

3.3. Comparison of Annual Variation in Carbon Sequestration of Major Plant Species. As shown in Table 3, Shorea robusta, Terminalia tomentosa, Lagerstroemia parviflora, Dalbergia latifolia, and Mallotus philippensis are the dominant plant species in these forests so the carbon sequestration per annum for these major species was compared in the forests. For this purpose, $Z$-test was used for 30 and more samples while paired samples $t$-test was used for less than 30 samples. The result showed that there was a clear variation in annual carbon sequestration per year of these major species in the forests at $5 \%$ level of significance. The reliable reasons could be the application of different types of silvicultural operations and the existing developmental stage of the plants during the study period.

\section{Discussion}

4.1. Carbon Stock in Different Plant Species and Their Dynamics. Shorea robusta, Terminalia tomentosa, Adina cordifolia, and Lagerstroemia parviflora are the major species in Terai, Nepal, so these are dominant in these forests. Hence, the carbon stock was higher in these species. No prior study has been undertaken to determine the species-wise carbon change in Nepal. In this regard, the forest resource assessment report [25] and some other researches have some focus on carbon stock. This report [25] showed that the carbon stock of Shorea robusta was nearly $52.31 \mathrm{tha}^{-1}$, which is close to the carbon stock of the same species in Gadhanta-Bardibash CFM. Moreover, the biomass table prepared by [26] showed that the biomass of a tree having $20 \mathrm{~cm}$ diameter has nearly 0.3 ton of carbon. Moreover, the study done in Terai showed that the carbon stock of $33 \mathrm{~cm}$ dbh of Shorea robusta was about 279.90 ton [27]. Another study done in Gujrat India showed that carbon stock of Terminalia tomentosa, Bombax ceiba, and Adina cordifolia was 5.14, 40.76, and 9.31 ton [28].

Obviously the carbon sequestration of dominant species in the forest was higher. So carbon sequestration rate was recorded higher in Shorea robusta, Terminalia tomentosa, Adina cordifolia, Lagerstroemia parviflora, and Mallotus 


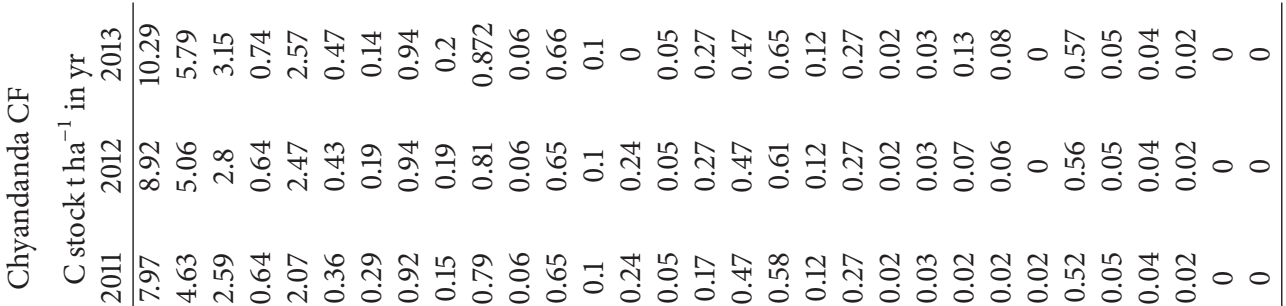

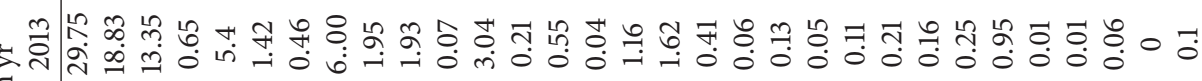
$\exists$

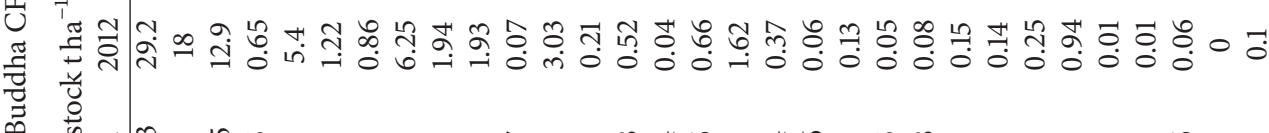

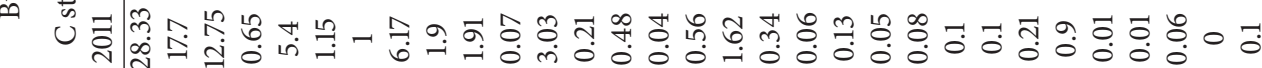

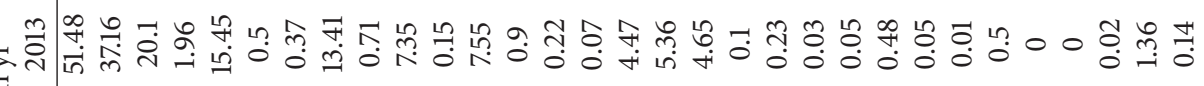

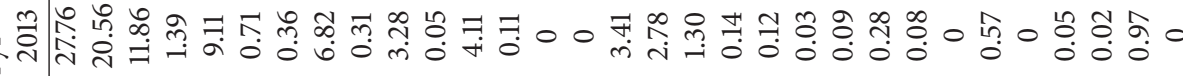

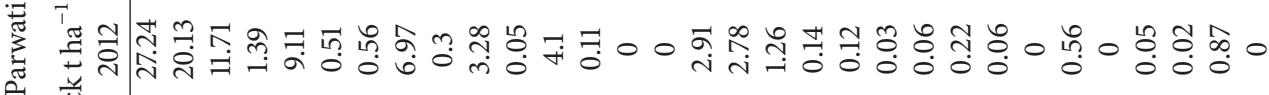

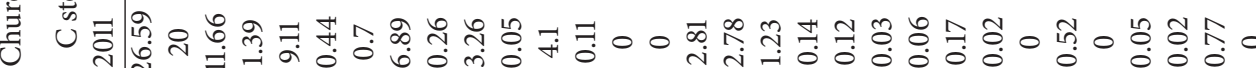

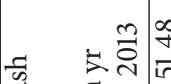

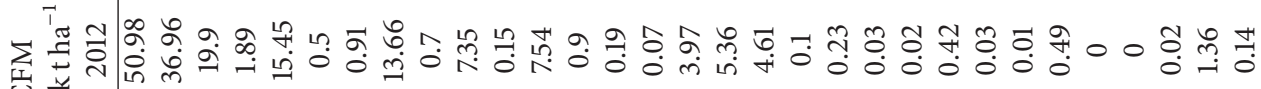
总

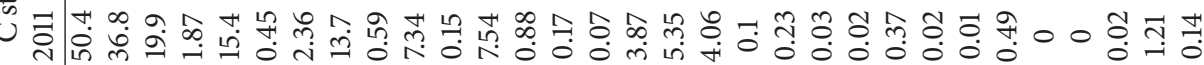

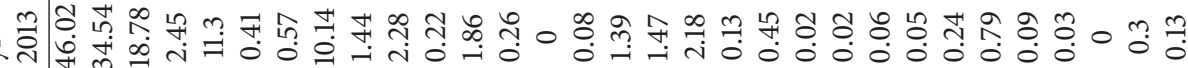
质

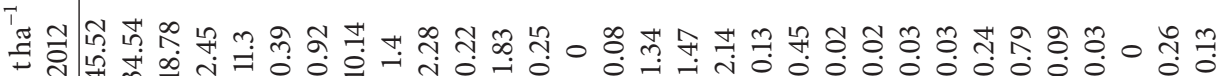
䓀

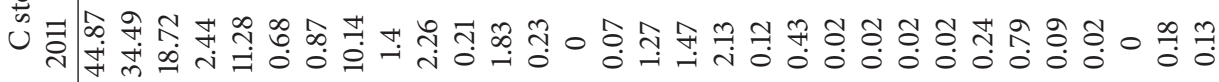

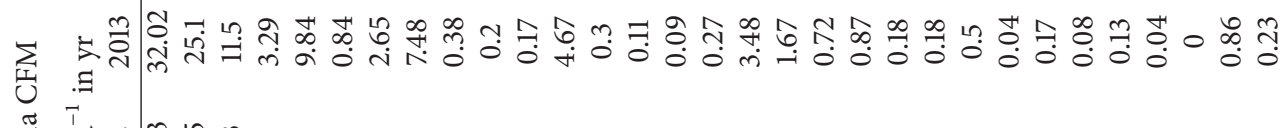

吾 $\sum_{i}^{\pi} \frac{\pi}{5}$

芷

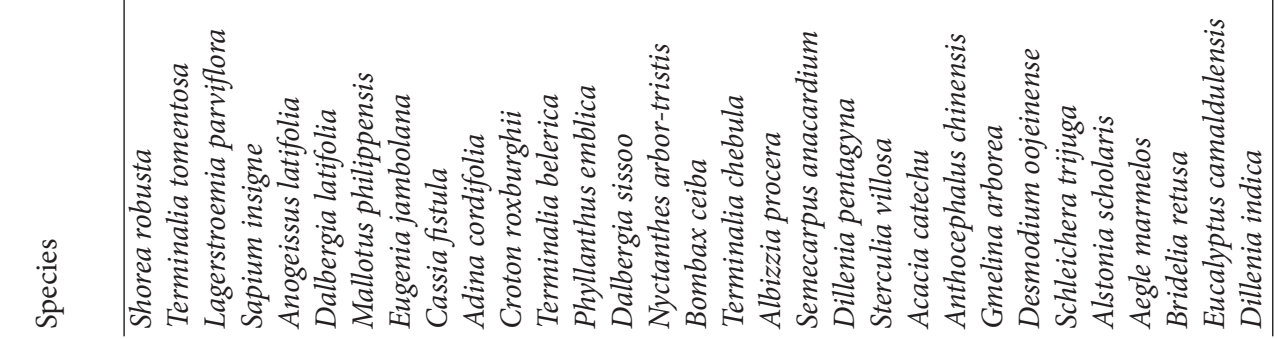




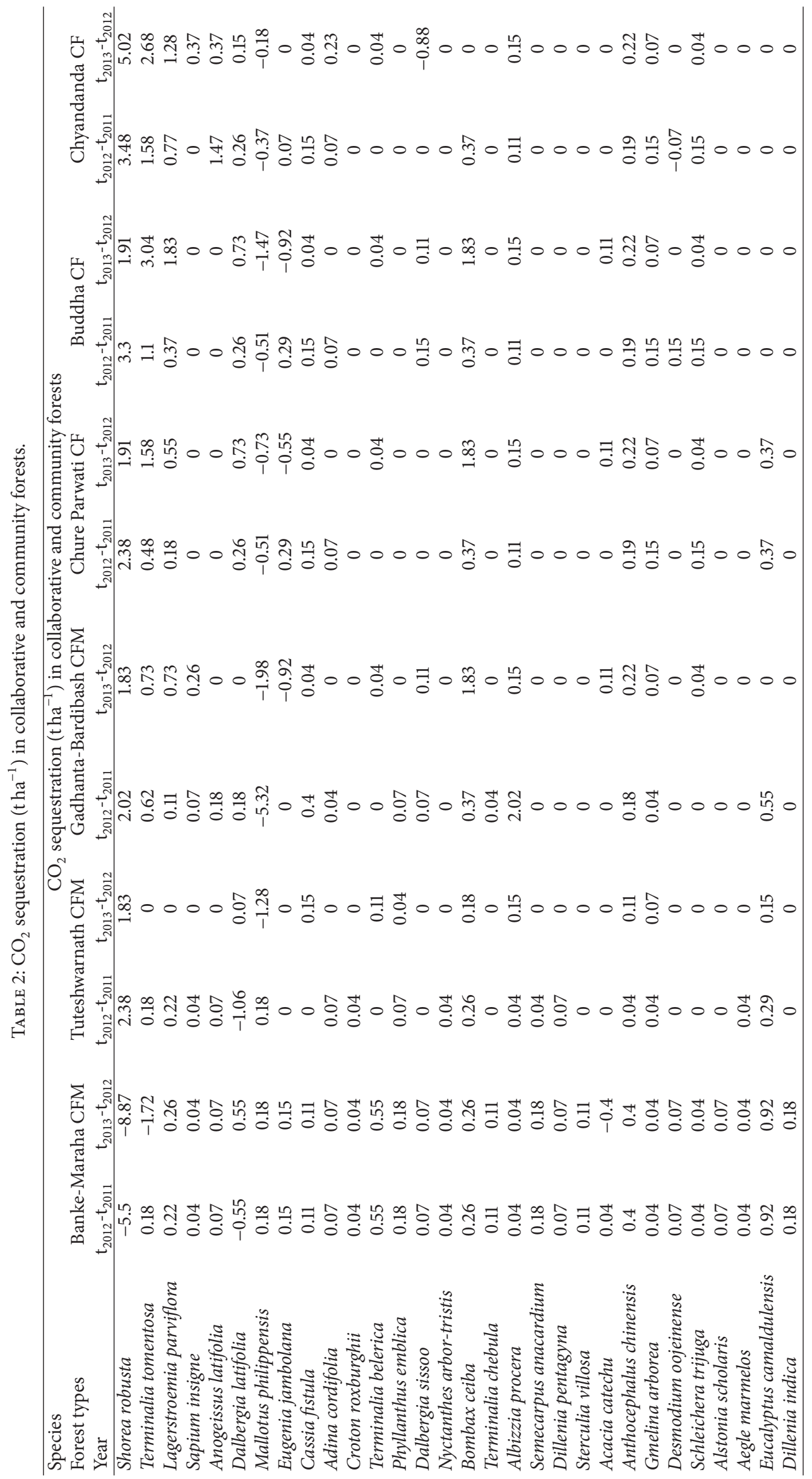


TABLE 3: Statistical comparison of carbon sequestration.

\begin{tabular}{|c|c|c|c|c|c|c|}
\hline Species & $\begin{array}{c}\text { Banke- } \\
\text { Maraha } \\
\text { CFM }\end{array}$ & $\begin{array}{l}\text { Tuteshwarnath } \\
\text { CFM }\end{array}$ & $\begin{array}{c}\text { Gadhanta- } \\
\text { Bardibash } \\
\text { CFM }\end{array}$ & $\begin{array}{c}\text { Chure Parwati } \\
\text { CF }\end{array}$ & Buddha CF & Chyandanda CF \\
\hline Test applied & \multicolumn{4}{|c|}{$Z$-test and $P$ value } & \multicolumn{2}{|c|}{$P$ value of paired samples $t$-test } \\
\hline Shorea robusta & 0.000 & 0.000 & 0.035 & 0.002 & 0.000 & 0.000 \\
\hline Terminalia tomentosa & 0.000 & 0.000 & 0.000 & 0.000 & 0.000 & 0.000 \\
\hline Lagerstroemia parviflora & 0.000 & 0.000 & 0.000 & 0.000 & 0.000 & 0.000 \\
\hline Dalbergia latifolia & 0.000 & 0.000 & 0.000 & 0.000 & 0.000 & 0.000 \\
\hline Mallotus philippensis & 0.000 & 0.000 & 0.000 & 0.000 & 0.000 & 0.000 \\
\hline
\end{tabular}

philippensis in comparison to other plant species in the forests. Another remarkable fact is that Terminalia tomentosa, Lagerstroemia parviflora, and Dalbergia latifolia have high timber value after Shorea robusta except Mallotus philippensis which is considered as the barrier for regeneration of other species [29]. So, forest technicians advise to remove this plant species in order to create open space for germination of other species. No study has yet been done to show the differences in carbon stock reference to plant species. A study done in India showed that carbon sequestration of Shorea robusta dominant forest was 11.37 ton per annum [30]; this value was higher than the highest rate of carbon sequestration in the same species of Chyandanda CF. A study conducted in central Himalaya of India showed an annual carbon sequestration rate of $3.45 \mathrm{t} \mathrm{ha}^{-1}$ in Shorea robusta [31] which is quite similar to the value obtained for Chyandanda CF between years 2011 and 2012. The study done in Terai showed that the carbon sequestration of Shorea robusta was $1.95 \mathrm{t} \mathrm{yr}^{-1}$ of plant aged 16 years [32]; this result was quite similar to the carbon sequestration of Chure Parwati and Buddha CF of $t_{2012}-t_{2011}$. The mean carbon sequestration in Uttaranchal, India, $3.7 \mathrm{tha}^{-1} \mathrm{yr}^{-1}$ and estimated carbon sequestration of Shorea robusta dominant forest in Ilam, Terai, showing about $11.37 \mathrm{tha}^{-1} \mathrm{yr}^{-1}$, were recorded [33]. There are many factors affecting the carbon sequestration rate; the major ones are biotic and abiotic factors [34]. Favorable climate and fertile soil favor the biomass and carbon growth in the plants. In addition, young staged plants and fast growing species have high sequestration capacity [35].

\section{Conclusion and Recommendation}

The carbon sequestration varied annually and according to plant species. Shorea robusta was the main species in these forests so it had the highest carbon stock. Similarly, carbon sequestration was found to be the highest in Chyandanda CF because of the presence of young plants at growing stage in this forest. However, there was a loss in carbon stock in Banke-Maraha CFM due to high amount of logging in this forest. This suggests the need of proper silvicultural implication in the CFs and CFMs of Terai region of Nepal that will remove the old and overmature trees from the forest. Old and overmature trees sequester carbon at a very low rate. Similarly, this will create desirable gaps in the forest and this gap dynamics would also allow young plants to grow and increase the carbon stock of the forest. Moreover, more studies related to the carbon stock growth based on plant age should be undertaken.

\section{Disclosure}

This paper is original and not published before and not submitted in any other journals.

\section{Competing Interests}

There is no conflict of interests regarding the publication of this paper.

\section{Authors' Contributions}

Mr. Utsab Thapa and Mr. Ram Asheshwar Mandal prepared the draft of the paper and Professors Pramod Kumar Jha, Ishwar Chandra Dutta, and Siddhi Bir Karmacharya arranged the results according to research objectives and finalized it.

\section{Acknowledgments}

The authors acknowledge chairmen and members of the concerned collaborative and community forests. Specifically the authors sincerely acknowledge Mr. Ragunath Prashad Yadav, chairperson of Banke-Maraha collaborative forest, Mr. Shree Prashad Singh, Mr. Vijay Yadav, and Mr. M. Ranjana Shrestha. The fieldwork was probably impossible without their support.

\section{References}

[1] J. Lal, Forest Management: Classical Approach and Current Imperstives, Division Deharadoon, Chaman Interprises, New Delhi, India, 2007.

[2] D. McKenna, S. Naumann, K. McFarland, A. Graf, and D. Evans, "Literature review, the ecological effectiveness of the natural 2000 network," ETC/BD Report to the EEA, The Ecological Effectiveness of the Natural, 2014.

[3] R. Costanza, R. D’Arge, R. de Groot et al., "The value of the world's ecosystem services and natural capital," Nature, vol. 387, no. 6630 , pp. 253-260, 1997. 
[4] D. U. Hooper and P. M. Vitousek, "The effects of plant composition and diversity on ecosystem processes," Science, vol. 277, no. 5330, pp. 1302-1305, 1997.

[5] P. Kenrick and P. R. Crane, "The origin and early evolution of plants on land," Nature, vol. 389, no. 6646, pp. 33-39, 1997.

[6] C. Parmesan and G. Yohe, "A globally coherent fingerprint of climate change impacts across natural systems," Nature, vol. 421, no. 2, pp. 37-42, 2003.

[7] J. A. Lau and P. Tiffin, "Elevated carbon dioxide concentrations indirectly affect plant fitness by altering plant tolerance to herbivory," Oecologia, vol. 161, no. 2, pp. 401-410, 2009.

[8] M. Khallaf, The Impact of Air Pollution on Health, Economy, Environment and Agricultural Sources, Tech Europe University Campus STeP R, 2011.

[9] J. Latham, M. Trivedi, R. Amin, and L. D’Arcy, A Sourcebook of Biodiversity Monitoring for REDD+, Zoological Society of London, London, UK, 2014.

[10] F. Greg and L. Donna, Early Lessons from Jurisdictional REDD+ and Low Emissions Development Programs. The Nature Conservation, Forest Carbon Partnership Facility, The World Bank, Washington, DC, USA, 2015.

[11] B. Mackey, C. Prentice, W. Steffen et al., "Untangling the confusion around land carbon science and climate change mitigation policy," Nature Climate Change, vol. 3, no. 1, pp. 552$557,2009$.

[12] G. Kissinger, M. Herold, and V. De, Drivers of Deforestation and Forest Degradation: A Synthesis Report for REDD+ Policymakers, Lexeme Consulting, Vancouver, Canada, 2012.

[13] A. Lisa, A. Simon, L. Nathaniel et al., IPCC Fifth Assessment Report Climate Change 2013: The Physical Science Basis Summary for Policymakers, Germany, IPCC, 2014.

[14] R. E. Gullison, P. C. Frumhoff, J. G. Canadell et al., "Tropical forests and climate policy," Science, vol. 316, no. 5827, pp. 985986, 2007.

[15] MoE, Nepal's Second National Communication Report, Ministry of Environment, Singhdurbar,, Kathmandu, Nepal, 2014.

[16] A. P. Kinzig, C. Perrings, F. S. Chapin III et al., "Paying for ecosystem services-promise and peril," Science, vol. 334, no. 6056, pp. 603-604, 2011.

[17] D. J. Nowak, J. T. Walton, J. C. Stevens, D. E. Crane, and R. E. Hoehn, "Effect of plot and sample size on timing and precision of urban forest assessments," Arboriculture and Urban Forestry, vol. 34, no. 6, pp. 386-390, 2008.

[18] B. Neupane and R. Sharma, "An assessment of the effect of vegetation size and type, and altitude on above ground plant biomass and carbon," Journal of Agriculture and Crop Research, vol. 2, no. 3, pp. 56-60, 2014.

[19] B. S. Jina, P. Sah, M. D. Bhatt, and Y. S. Rawat, "Estimating carbon sequestration rates and total carbon stockpile in degraded and non-degraded sites of Oak and Pine forest of Kumaun Central Himalaya," Journal of Ecoprint, vol. 15, no. 1, pp. 75-81, 2009.

[20] J. Chave, C. Andalo, S. Brown et al., "Tree allometry and improved estimation of carbon stocks and balance in tropical forests," Oecologia, vol. 145, no. 1, pp. 87-99, 2005.

[21] K. MacDicken, A Guide to Monitoring Carbon Storage in Forestry and Agroforestry Projects, Winrock International Institute for Agricultural Development, Arlington, Va, USA, 1997.
[22] IPCC, "IPCC guidelines for national greenhouse gas inventories," in National Greenhouse Gas Inventories Programme, H. S. Eggleston, L. Buendia, K. Miwa, T. Ngara, and K. Tanabe, Eds., Institute for Global Environmental Strategies (IGES), Hayama, Japan, 2006.

[23] C. Wu and C. Jiahua, Sampling and Experimental Design, Department of Statistics and Actuarial Science University of Waterloo, Ghent, Belgium, 2006.

[24] I. P. Sapkota, M. Tigabu, and P. C. Odén, "Spatial distribution, advanced regeneration and stand structure of Nepalese Sal (Shorea robusta) forests subject to disturbances of different intensities," Forest Ecology and Management, vol. 257, no. 9, pp. 1966-1975, 2009.

[25] FRA/DFRS, Tarai Forests of Nepal (2010-2012), Forest Resource Assessment Nepal Project/Department of Forest Research and Survey, Kathmandu, Nepal, 2014.

[26] P. Tamrakar, Biomass and Volume Tables with Species Description for Community Forest Management, Compiled by P. R. Tamrakar, Ministry of Forest and Soil Conservation, Kathmandu, Nepal, 2000.

[27] K. Acharya, R. Regmi, and B. Acharya, Biomass and Volume Tabels for Terai Sal (Shorea robusta) Forest of Nepal, Department of Forest Research and Survey, Ministry of Forests and Soil Conservation, Kathmandu, Nepal, 2003.

[28] I. Pandya, H. Salvi, O. Chahar, and N. Vaghela, "Quantitative analysis on carbon storage of 25 valuable tree species of gujarat, incredible India," Indian Journal of Scientific Research, vol. 4, no. 1, pp. 137-141, 2013.

[29] J. Sharma and R. Varma, "A review on endangered plant of Mallotus philippensis," Pharmacolog, vol. 3, no. 1, pp. 1256-1265, 2011.

[30] A. Tewari and B. Karky, Carbon Management Methodology and Results in Reducing Carbon Emission through CommunityManaged Forests in the Himalaya, Hill Side Press, Kathmandu, Nepal, 2007.

[31] V. Singh, A. Tewari, J. Ram, and C. Singh, "Aspect related changes in biomass stocks and carbon sequestration rates of Shorea robusta (Sal) forest of Central Himalaya," Report and Opinion, vol. 1, no. 2, pp. 56-60, 2009.

[32] DFRS, Managing degraded Shorea robusta forests in Terai of Nepal, 2009.

[33] A. Tewari and B. Karky, Carbon Measurement Methodology and Results, Reducing Carbon Emission through Community Managed Forests in Himalayan, 2007.

[34] R. G. Newell and R. N. Stavins, "Climate change and forest sinks: factors affecting the costs of carbon sequestration," Journal of Environmental Economics and Management, vol. 40, no. 3, pp. 211-235, 2000.

[35] D. J. Nowak, E. J. Greenfield, R. E. Hoehn, and E. Lapoint, "Carbon storage and sequestration by trees in urban and community areas of the United States," Environmental Pollution, vol. 178, pp. 229-236, 2013. 

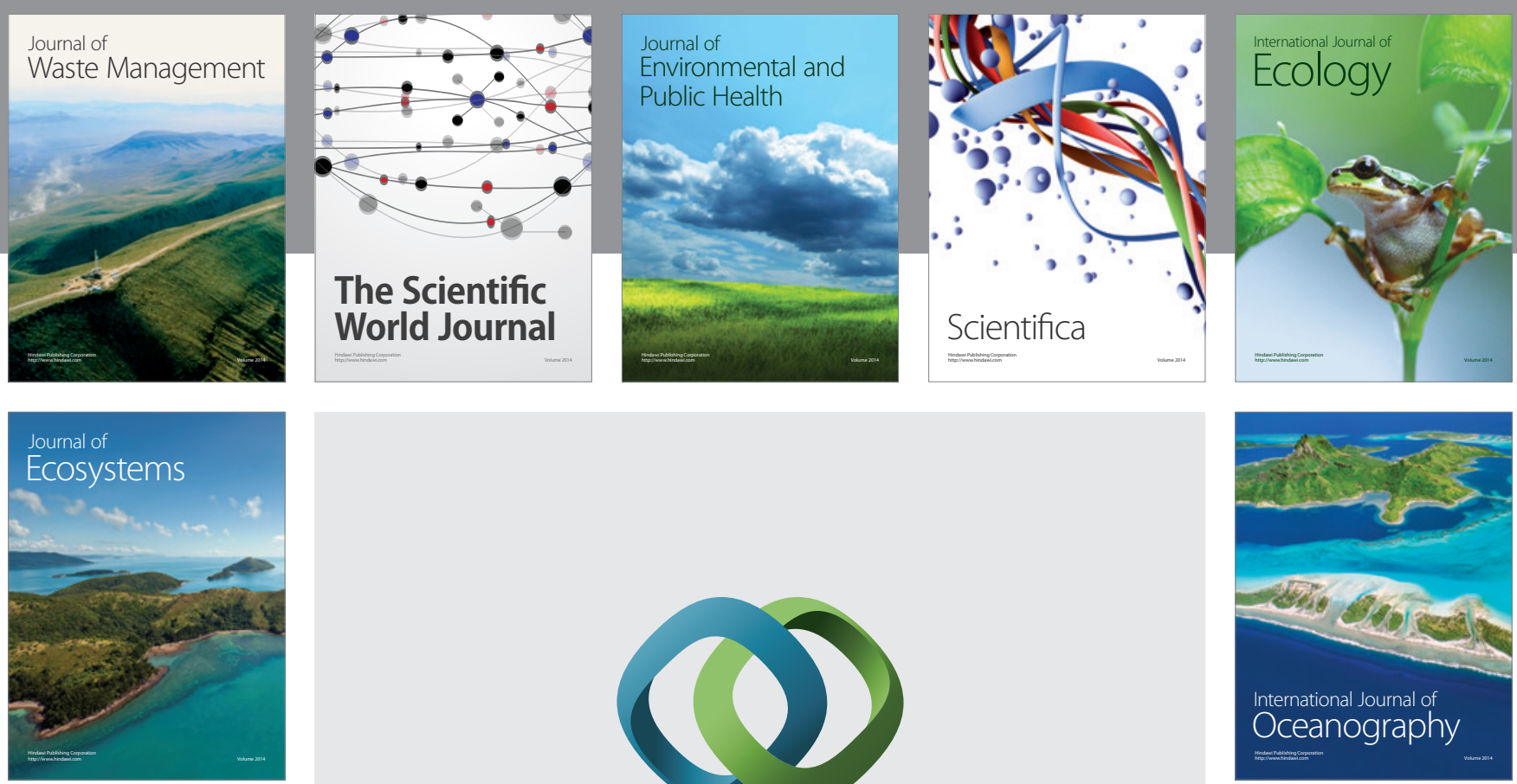

The Scientific World Journal
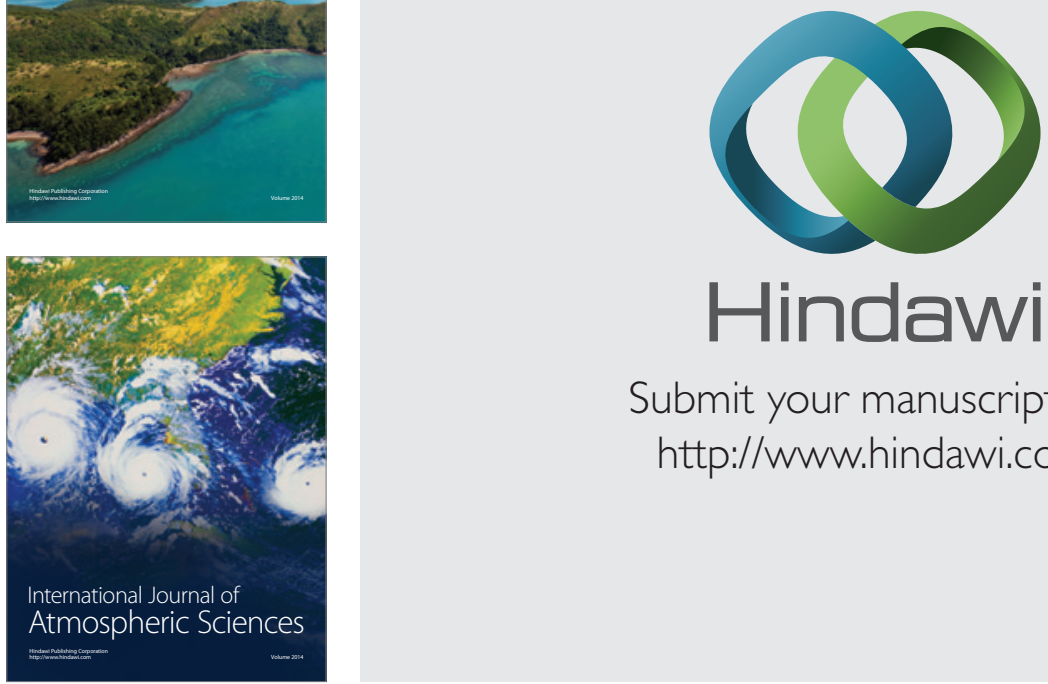

\section{Hindawi}

Submit your manuscripts at

http://www.hindawi.com
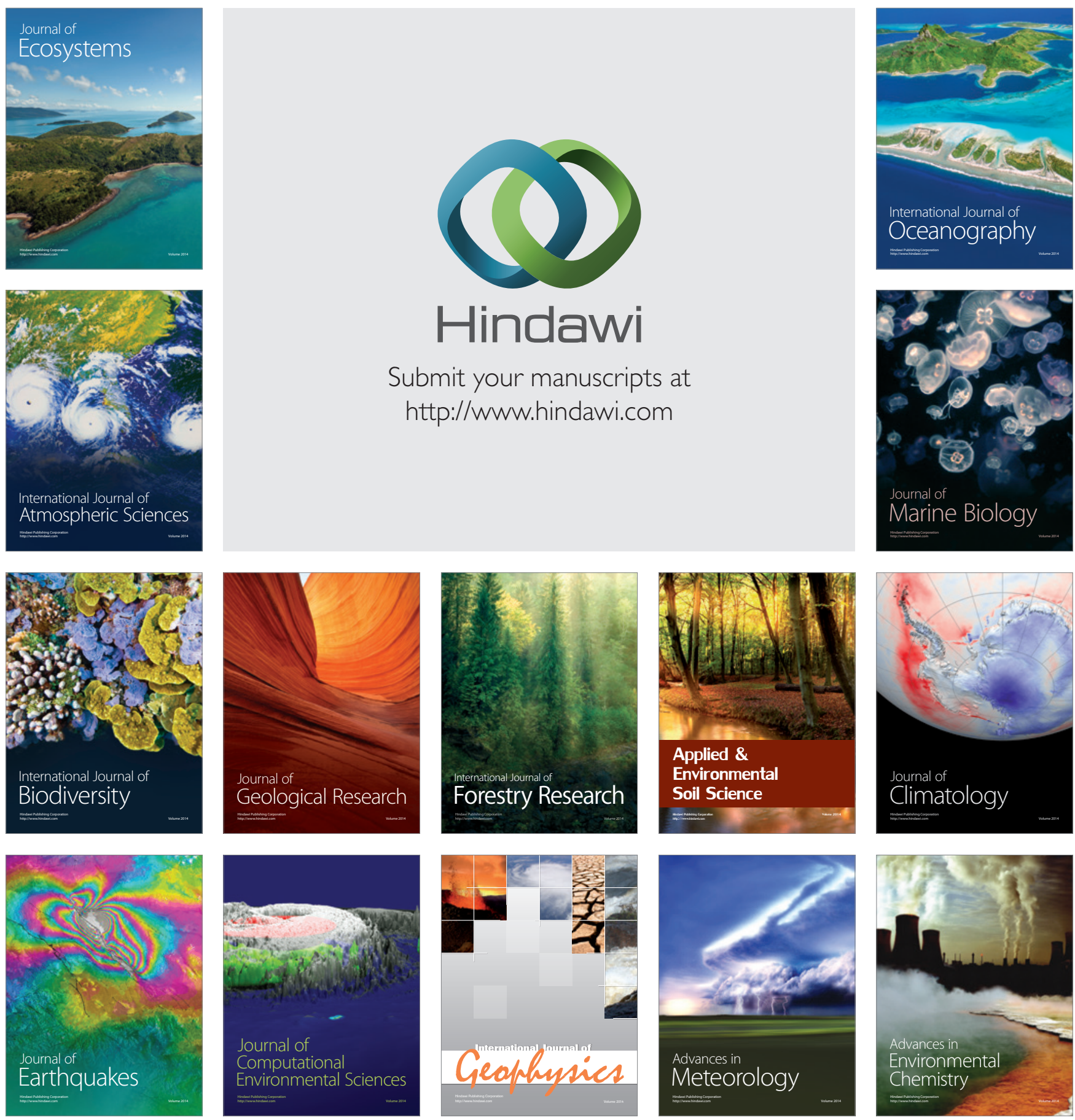